with acute myeloid leukaemia is of great clinical importance. Water intoxication may produce confusion (Kaye, 1966) and disorientation (Weissman et al., 1971)-symptoms which can readily be confused with the terminal state of acute leukaemia. Intravenous infusion can be hazardous in these patients. Attention to the underlying electrolyte imbalance will lead to the correct diagnosis, which is reversible by water restriction.

We appreciate the kind co-operation of Dr. C. G. Beardwell, of the Clinical Research Laboratories, Christie Hospital, and Holt Radium Institute, Withington, Manchester, in performing radioimmunoassay for the determination of plasma arginine vasopressin. Our thanks are due to Dr. J. D. Swales for his helpful criticism.

\section{References}

Barnes, J. M. (1940). British fournal of Experimental Pathology, 21, 264.
Bartter, F. C., and Schwartz, W. B. (1967). American fournal of Medicine, 42, 790.

Beardwell, C. G. (1971). fournal of Clinical Endocrinology, 33, 254.

Fessas, P., Wintrobe, M. M., Thompson, R. B., and Cartwright, G. E. (1954). Archives of Internal Medicine, 94, 384.

Fine, D., and Shedrovilzky, H. (1970). Annals of Internal Medicine, 72, 83. Kaye, M. (1966). American Fournal of Medicine, 41, 910.

Lange, W. E. de, and Doorenbos, H. (1972). In Side Effects of Drugs, ed. L. Meyler, vol. VII, p. 525. Amsterdam, Excerpta Medica.

McCance, R. A., and Widdowson, E. M. (1969). The Composition of Foods, 3rd edn. London, H.M.S.O

Mattingly, D., Dennis, P. M., Pearson, J., and Cope, C. L. (1964). Lancet, 2, 1046. Osserman, E. F., and Lawlor, D. P. (1966). Fournal of Experimental Medicine,

Sampey, J. R. (1963). American fournal of Pharmacy, 135, 380.

Sawyer, R. B., Spencer, J. R., Dudzenski, P. J., and Enis, J. E. (1967). American fournal of Surgery, 114, 691.

Schwartz, W. B., Bennett, W., Corelop, S., and Bartter, F. C. (1957) American fournal of Medicine, 23, 529.

Simons, K., and Weber, T. (1966). Biophysics Acta, 117, 201.

Spittle, M. F. (1966). Postgraduate Medical Fournal, 42, 523.

Weissman, P. N., Shenkman, L., and Gregerman, R. I. (1971). New England fourn,ll of Medicine, 284, 65 .

\title{
Remission of Diabetes Mellitus during Pregnancy
}

\author{
JOANNA SHELDON, TIMOTHY COLEMAN
}

British Medical fournal, 1974, 1, 55-57

\section{Summary}

Two cases are reported in which a remission of diabetes was sustained throughout pregnancy. This seemed to be due in part to improved $\beta$-cell function consequent on restoration of normoglycaemia before pregnancy, and in part to an increase in insulin sensitivity during pregnancy, which in the first case disappeared very rapidly after delivery.

\section{Introduction}

Though partial remission of diabetes is not uncommon in young diabetics soon after control has been established the return to normal glucose tolerance is rare (Harwood, 1957; Peck et al., 1958; Stutman and Hayes, 1959; Hines and Kessler, 1961; Field et al., 1961; Brereton, 1968). For glucose tolerance to remain normal throughout pregnancy in a diabetic is even more remarkable. It seemed of interest, therefore, to report two cases in which remission of diabetes persisted during pregnancy, the response to $50-\mathrm{g}$ oral glucose tolerance tests remaining normal throughout in one and nearly normal in the other.

\section{Case 1}

This patient was found to be a diabetic at the age of 29 when she presented with a three-month history of recurrent boils. There were no other symptoms and she was of normal weight. The blood glucose in the mid-morning at her first clinic visit was $302 \mathrm{mg} / 100$ $\mathrm{ml}$ (G.O.D. period method, Boehringer). After one month on a $150-\mathrm{g}$ carbohydrate diet her mid-morning blood glucose was $334 \mathrm{mg} / 100$ $\mathrm{ml}$. She was therefore given chlorpropamide $250 \mathrm{mg}$ daily (fig. 1). After starting chlorpropamide, and until after delivery, all midmorning blood glucose values were below $120 \mathrm{mg} / 100 \mathrm{ml}$ (mean

Royal Sussex County Hospital, Brighton BN2 5BE

JOANNA SHELDON, M.D., M.R.C.P. Consultant Physician

TIMOTHY COLEMAN, M.B., B.S., Research Registrar

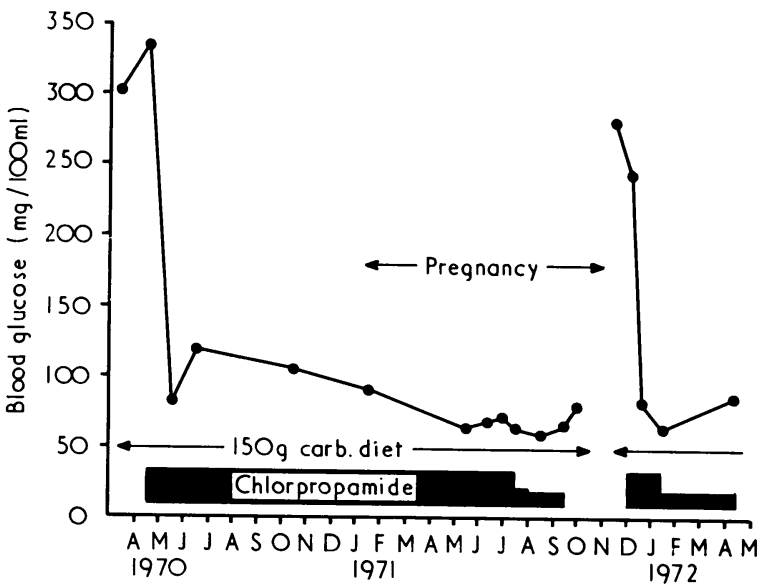

FIG. 1-Case 1. Mid-morning blood glucose values over two-year period. Readings taken two to three hours after a meal.

$83 \mathrm{mg} / 100 \mathrm{ml})$. All urine tests done twice daily throughout pregnancy were negative for sugar. Chlorpropamide was discontinued at 32 weeks of pregnancy. Between the $33 \mathrm{rd}$ and 37 th weeks four 50 -g oral glucose tolerance tests were done (table I). The highest one-hour value was $173 \mathrm{mg} / 100 \mathrm{ml}$ and the highest two-hour value $123 \mathrm{mg} / 100 \mathrm{ml}$. (A $100-\mathrm{g}$ oral glucose tolerance test at 35 weeks, however, produced a two-hour blood glucose of $175 \mathrm{mg} / 100$ $\mathrm{ml}$, and response to a cortisone glucose tolerance test (Fajans and Conn, 1961) was grossly abnormal at 38 weeks). Serum insulin (Hales and Randle, 1963) was low throughout all these tests for this stage of pregnancy. Plasma placental lactogen (Letchworth et al., 1971) estimated during each test was within the normal range (table I). Twenty-four-hour urinary oestriol (Brombacher et al., 1968) measured on 11 occasions from the 32nd week was also normal, ranging from 10.5 to $44.3 \mathrm{mg} / 24$ hours.

Glycosuria reappeared four days after delivery and glucose tolerance deteriorated rapidly thereafter (fig. 2).

The baby, delivered at 38 weeks, was a typical infant of a diabetic mother, weighing $4,360 \mathrm{~g}$ at birth. The placenta was also a little heavy $(51 \mathrm{~g})$. The baby rapidly became hypoglycaemic, cord blood glucose dropping from $88 \mathrm{mg} / 100 \mathrm{ml}$ at birth to less than $10 \mathrm{mg} / 100 \mathrm{ml}$ one hour later, when an intravenous glucose infusion was started. In spite of a continuous glucose infusion and glucagon 
TABLE I-Case 1. 50-g Oral Glucose Tolerance Tests at 33-37 Weeks

\begin{tabular}{|c|c|c|c|c|c|c|c|c|c|c|c|c|}
\hline \multirow[b]{2}{*}{ Time $(\mathrm{hr})$ : } & \multicolumn{4}{|c|}{$\begin{array}{l}\text { Blood Glucose } \\
(\mathrm{mg} / 100 \mathrm{ml})\end{array}$} & \multicolumn{4}{|c|}{$\underset{(\mathrm{pU} / \mathrm{ml})}{\text { Serum Insulin }}$} & \multicolumn{4}{|c|}{$\begin{array}{l}\text { Placental Lacto- } \\
\text { gen }(\mathrm{pg} / \mathrm{ml})\end{array}$} \\
\hline & 0 & $\frac{1}{2}$ & 1 & 2 & 0 & $\frac{1}{2}$ & 1 & 2 & 0 & $\frac{1}{2}$ & 1 & 2 \\
\hline $\begin{array}{l}33 \text { Weeks } \\
34 \quad \text { " } \\
36 \quad " \\
37 \quad "\end{array}$ & $\begin{array}{l}56 \\
50 \\
61 \\
39\end{array}$ & $\begin{array}{l}104 \\
\frac{100}{101}\end{array}$ & \begin{tabular}{l|}
124 \\
173 \\
153 \\
123
\end{tabular} & $\begin{array}{l}103 \\
115 \\
123 \\
85\end{array}$ & $\begin{array}{l}-7 \\
4 \\
4\end{array}$ & $\begin{array}{l}\overline{19} \\
13 \\
16\end{array}$ & $\begin{array}{l}\overline{15} \\
15 \\
12\end{array}$ & $\begin{array}{r}\overline{17} \\
14 \\
9\end{array}$ & $\begin{array}{l}\overline{5 \cdot 4} \\
3 \cdot 5 \\
8 \cdot 4\end{array}$ & $\begin{array}{l}\overline{5 \cdot 7} \\
4 \cdot 5 \\
7 \cdot 0\end{array}$ & $\begin{array}{l}\overline{5 \cdot 5} \\
5 \cdot 4 \\
7 \cdot 8\end{array}$ & $\begin{array}{l}\overline{6 \cdot 2} \\
5 \cdot 5 \\
8 \cdot 8\end{array}$ \\
\hline
\end{tabular}
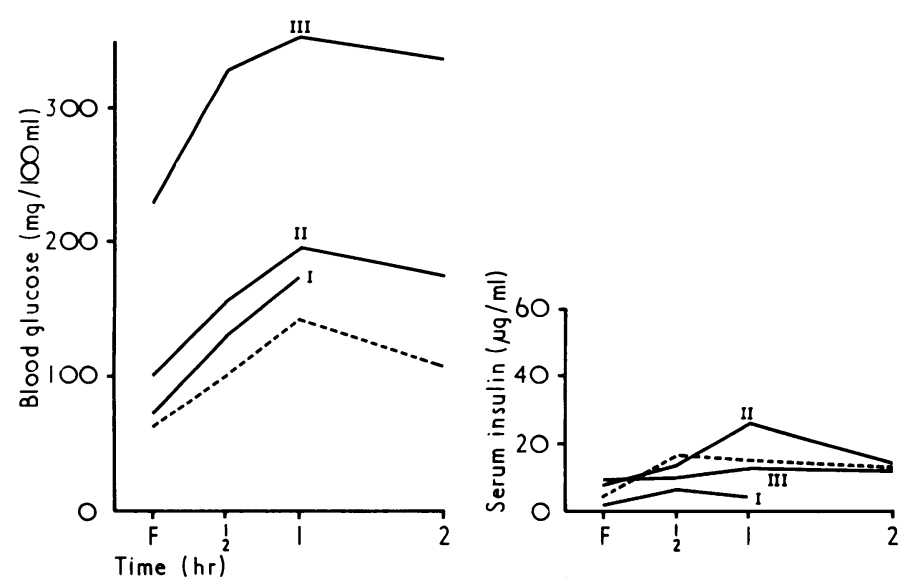

FIG. 2-Case 1. Response to $50 \mathrm{~g}$ oral glucose tolerance tests 8 days (I), 9 days (II), and 21 days (III) after delivery. Dotted line indicates mean of four tests at 33-37 weeks of pregnancy. F .. Fasting.

the baby remained hypoglycaemic for four days. Serum insulin, measured on two occasions during this hypoglycaemic phase, was only 10 and $7 \mu \mathrm{U} / \mathrm{ml}$.

\section{Case 2}

This patient was found to be diabetic at the age of 33, again presenting with recurrent boils. She was obese, weighing $113 \mathrm{~kg}$. The blood glucose was $271 \mathrm{mg} / 100 \mathrm{ml}$ in the mid-morning at her first clinic visit, and she was put on a 1,000-calorie diet and slowacting phenformin $50 \mathrm{mg} /$ day (fig. 3). All urine tests done twice daily throughout pregnancy were negative for sugar. Phenformin was stopped at eight weeks of pregnancy by which time she had lost $14 \mathrm{~kg}$. Tolerance tests with $50 \mathrm{~g}$ oral glucose were performed at 25, 30, and 37 weeks (table II). The highest two-hour blood glucose value was $125 \mathrm{mg} / 100 \mathrm{ml}$ at 37 weeks, though a $100-\mathrm{g}$ oral glucose tolerance test at this time gave a two-hour value of $175 \mathrm{mg} / 100 \mathrm{ml}$. Her serum insulin was low during these tests for this stage of pregnancy. Twenty-four-hour urinary oestriol at the 33rd and 38th weeks was normal at 25 and $48 \mathrm{mg} / 24$ hours, as was urinary free cortisol (Mattingly, 1962) at 37 weeks. Placental lactogen was nor-

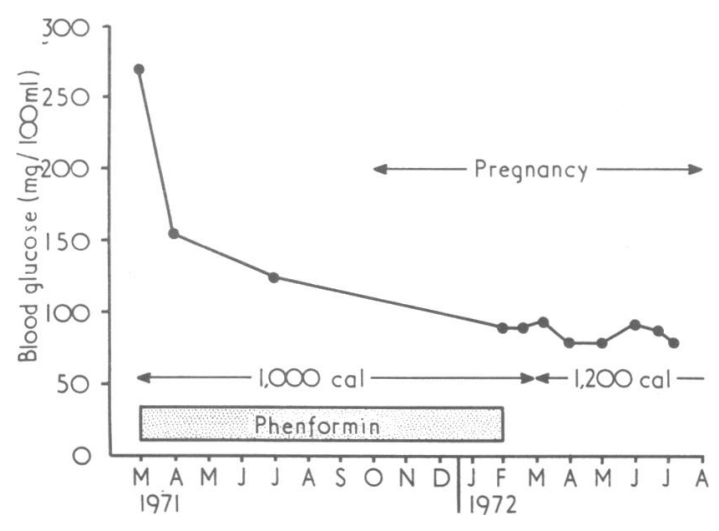

FIG. 3-Case 2. Mid-morning blood glucose values over 19 months from time of first clinic visit. Readings taken two to three hours after a meal.
TABLE II-Case 2. Results of 50-g Oral Glucose Tolerance Tests at 25, 30, and 37 Weeks

\begin{tabular}{|c|c|c|c|c|c|c|c|c|}
\hline \multirow[b]{2}{*}{ Time $(\mathrm{hr})$ : } & \multicolumn{4}{|c|}{ Blood Glucose (mg/100 ml) } & \multicolumn{4}{|c|}{ Serum Insulin $(p U / m l)$} \\
\hline & 0 & $\stackrel{1}{2}$ & 1 & 2 & 0 & 3 & 1 & 2 \\
\hline $\begin{array}{l}25 \text { Weeks } \\
30 \quad ", \\
37 \quad "\end{array}$ & $\begin{array}{l}94 \\
77 \\
87\end{array}$ & $\begin{array}{l}162 \\
131 \\
144\end{array}$ & $\begin{array}{l}151 \\
178 \\
188\end{array}$ & $\begin{array}{l}107 \\
104 \\
125\end{array}$ & $\begin{array}{l}36 \\
20 \\
16\end{array}$ & $\begin{array}{l}47 \\
36 \\
20\end{array}$ & $\begin{array}{l}53 \\
28 \\
34\end{array}$ & $\begin{array}{l}34 \\
24 \\
25\end{array}$ \\
\hline
\end{tabular}

mal at $5.7 \mu \mathrm{g} / \mathrm{ml}$ at 37 weeks. Fasting plasma glucagon (Bloom, 1972) was $140 \mathrm{pg} / \mathrm{ml}$ at 37 weeks, which is in the normal nonpregnani range. Plasma chorionic gonadotrophin (Wylde et al., 1967) was $10.8 \mathrm{IU} / \mathrm{ml}$ at 37 weeks.

The infant was overweight at $4,470 \mathrm{~g}$ and rapidly became hypoglycaemic, the cord blood glucose falling from $111 \mathrm{mg} / 100 \mathrm{ml}$ at birth to $18 \mathrm{mg} / 100$ at one hour. Blood glucose values became normal by the third day. An intravenous glucose tolerance test, using $0.5 \mathrm{~g}$ glucose $/ \mathrm{kg}$ starting one hour after birth, gave serum insulin values of $18,100,68$, and $19 \mu \mathrm{U} / \mathrm{ml}$ before and at 2,5 , and 30 minures after the glucose load. These insulin values werz low by comparison with figures obtained from infants of diabetic mothers not trcated with insulin (Isles et al., 1968).

\section{Discussion}

Blood glucose and insulin values in the 50-g oral glucose tolerance tests in these two patients during pregnancy were compared with the mean values obtained in 15 non-diabetic pregnancies at 32 weeks by Campbell et al. (1971). Blood glucose rose a little higher in both our patients than in these non-diabetics but was neventheless within the generally accepted normal range in case 1 and almost within it in case 2. Both patients, however, had insulin values much lower than the mean values obtained by Campbell et al., indicating insulin deficiency.

The association of such low serum insulin values with virtually normal glucose tolerance indicates a degree of insulin sensitivity remarkable in the pregnant diabetic, in whom insulin antagonism usually develops (Kalkhoff et al., 1964).

It seems likely that in these two patients $\beta$-cell function improved before they became pregnant as a result of the maintenance of normoglycaemia consequent on diet and chlorpropamide in the first case, and diet-with appreciable weight loss-and phenformin in the second. An increased insulin response to glucose is known to occur in mild diabetics as blood glucose levels are reduced by carbohydrate restriction (Rudnick and Taylor, 1965) or sulphonylurea treatment (Sheldon et al., 1966). Towards the end of pregnancy, however, both patients showed evidence of increased insulin sensitivity, which was particularly evident in case 1 . This seemed likely to be due to some factor specifically associated with pregnancy, as glucose tolerance in this case deteriorated so rapidly after delivery. For this reason it seemed unlikely to be related to the previous chlorpropamide treatment. There was, however, no evidence that this increased sensitivity to insulin was due to deficiency of placental lactogen or cortisol. In case 2 plasma glucagon at term was normal by non-pregnant standards, and oestriol excretion was within the normal range in both patients. The nature of their increased insulin sensitivity remains obscure.

Both infants were overweight and both developed neonatal hypoglycaemia, which was particularly severe and prolonged in case 1 in spite of maternal blood glucose levels having remained normal or near normal throughout pregnancy. Insulin values in these babies were low, suggesting that they too may have been unusually sensitive to insulin rather than that their hypoglycaemia was due to fetal hyperinsulinism, which is the usual explanation for hypoglycaemia in infants of diabetic mothers, being a consequence of maternal hyperglycaemia.

We wish to thank Dr. Stephen Bloom for measuring plasma glucagon, Dr. T. Chard and Miss Eleanor Cohen for measuring placental lactogen, Dr. V. H. T. James for measuring urinary 
free control, Dr. K. Bagshaw for measuring chorionic gonadotrophin, and Dr. Trevor Mann and Dr. Frank Nash for permission to study the infants. We should also like to thank Dr. K. W. Taylor for his advice and encouragement and for allowing us to use laboratory facilities at the University of Sussex.

ADDENDUM.-Since submitting this paper for publication one of these patients (case 1) again became pregnant. Her diabetes improved progressively during pregnancy and at 37 weeks a 50-g oral glucose tolerance test gave blood sugars when fasting and half an hour, one hour and two hours after glucose of $53,98,102$, and $138 \mathrm{mg} / 100 \mathrm{ml}$. The chlorpropamide was discontinued at 34 weeks. At 38 weeks she was delivered by caesarean section of an infant weighing 4,650 $\mathrm{g}$ which died at birth. There was gross hypentrophy and hyperplasia of the fetal islets, which presumably was not consequent on maternal hyperglycaemia but was possibly due to the chlorpropamide treatment. Once again her diabetes deteriorated rapidly immediately after delivery. The fasting blood sugar two days after delivery was $195 \mathrm{mg} / 100 \mathrm{ml}$.

\section{References}

Bloom, S. R. (1972). Gut, 13, 520.

Brereton, R. B. (1968). Delaware Medical fournal, 40, 37

Brombacher, P. J., Gijzen, A. H., and Verheesen, P. E. (1968). Clinica Chimica Acta, 20, 360.

Campbell, N., Pyke, D. A., and Taylor, K. W. (1971). fournal of Obstetrics and Gynaecology of the British Commonwealth, 78, 498.

Fajans, S. S., and Conn, J. W. (1961). Diabetes, 10, 63.

Field, J. B., Johnson, P., and Herring, B. (1961). Fournal of Clinical Investigation, 40, 1672.

Hales, C. N., and Randle, P. J. (1963). Biochemical fournal, 88, 137.

Harwood, R. (1957). New England fournal of Medicine, 257, 257.

Hines, J. J., and Kessler, D. L. (1961). Annals of Internal Medicine, 55, 314.

Isles, T. E., Dickson, M., and Farquhar, J. W. (1968). Pediatric Research, 2, 198.

Kalkhoff, R., et al. (1964). Transactions of the Association of American Physicians, 77, 270 .

Letchworth, A. T., Boardman, R. J., Bristow, C., London, J., and Chard, T. (1971). Fournal of Obstetrics and Gynaecology of the British Commonwealth, 78,542 .

Mattingly, D. (1962). Journal of Clinical Pathology, 15, 374.

Peck, F. B., jun., Kirtlev, W. R., and Peck, F. B. (1958). Diabetes, 7, 93.

Rudnick, P. A., and Taylor, K. W. (1965). British Medical fournal, 1, 1225.

Sheldon, J., Taylor, K. W., and Anderson, J. (1966). Metabolism, 15, 874.

Stutman, L. J., and Hayes, J. D. (1959). Diabetes, 8, 189.

Wylde, C., Orr, A. H., and Bagshaw, K. D. (1967). fournal of Endocrinology, 37, 23.

\title{
Vitamin A, Pregnancy, and Oral Contraceptives
}

\author{
JENNIFER WILD, C. J. SCHORAH, R. W. SMITHELLS
}

British Medical fournal, 1974, 1, 57-59

\begin{abstract}
Summary
It has been shown that women receiving oral contraceptives have increased levels of serum vitamin A. High vitamin $A$ levels may constitute a teratogenic hazard and it has been suggested that women who conceive soon after discontinuing oral contraceptive therapy may be especially at risk to this hazard.

We have confirmed a significant increase in vitamin $A$ levels in women taking oral contraceptives. During early pregnancy there is no significant difference in vitamin $A$ levels between women who have recently been taking oral contraceptives and those who have not. We have been unable to show that either taking oral contraceptives shortly before pregnancy or a high vitamin A level during the first trimester of pregnancy, comparable to that of a woman taking oral contraceptives, has any detrimental effect on the outcome of pregnancy. It seems unlikely that women who conceive soon after discontinuing oral contraception run any teratogenic risk from increased vitamin A levels.
\end{abstract}

\section{Introduction}

Since the introduction of synthetic steroids as a method of birth control there have been numerous reports of side effects and alterations in biochemical values among women taking these preparations. Gal et al. (1971) noted a significant increase in plasma vitamin $\mathbf{A}$ in women taking oral contraceptives. Briggs

\footnotetext{
Department of Paediatrics and Child Health, Leeds University,
Leeds LS1 3ET

JENNIFER WILD, B.sC., Chief Technician in Paediatric Research

C. J. SCHORAH, B.SC., PH.D., Lecturer in Chemical Pathology

R. W. SMITHELLS, M.B., F.R.C.P., Professor of Paediatrics and Child

Health
}

et al. (1972) also showed that women taking oral contraceptives had a significantly higher plasma vitamin $\mathbf{A}$ level than untreated controls, whereas the vitamin A levels of women receiving a long-acting, parenterally-administered progestogen contraceptive were similar to control $\mathrm{v}$ lues.

The importance of this lies in the possible teratogenic effect of excess vitamin A. Several workers have shown that the administration of large doses of vitamin A to pregnant animals may be associated with an increased incidence of congenital malformations (Cohlan, 1954; Giroud, 1960). This effect is enhanced by cortisone (Woollam and Millen, 1960).

In the field of human teratology, Pilotti and Scorta (1965) described a case of hypervitaminosis $\mathbf{A}$ in an Italian woman. She ingested excessive amounts of vitamins A and D $(40,000$ and 600,000 IU respectively) daily for a month at the beginning of pregnancy and gave birth to a child who at necropsy showed malformations of the urogenital system.

Gal et al. (1972) found significantly higher postpartum serum vitamin A levels in mothers of children with defects of the central nervous system than in mothers of normal children. Their study was retrospective, however, and the authors themselves pointed out the need to determine whether the high serum vitamin A level is present in early pregnancy and could be a primary cause of malformations or whether it is a secondary response to the presence of a malformed fetus. If a high serum vitamin A level can be a primary cause of malformations, and if the vitamin A level remains high after stopping oral contraception, then those women who conceive immediately after stopping oral contraception may run an increased risk of bearing malformed children. We have had the opportunity to study the serum vitamin A levels of women in early pregnancy, to relate these to the administration of oral contraceptives immediately preceding conception, and to observe the outcome of the pregnancies.

\section{Subjects and Methods}

As part of a large-scale, prospective study of nutrition in early pregnancy blood samples were taken from several hundred mothers in the first 15 weeks of pregnancy for analysis of several 